\title{
SHAPING HIGH-PERFORMANCE WORK SYSTEMS THROUGH HRM PRACTICES
}

\author{
Milena Gojny-Zbierowska \\ University of Economics in Katowice, \\ Department of Human Resource Management, Katowice, Poland \\ e-mail: milena.gojny@ue.katowice.pl
}

\begin{abstract}
Purpose: The analysis of the meaning of HPWS practices for employee and the identification of the positive human resource management practices essential for high performance work systems.

Methodology: Literature review.

Findings: Many research show that the HPWP implementation yields results in the form of increased productivity, increased in efficiency and benefits. There are many examples of the relationship between HPWS and various aspects of the functioning of the organization. In the debate on HPWS meaning for employee well-being there has been a polarization of opinions, some researchers have an enthusiastic attitude to the model, some are highly critical. Some aspects related to the system transformation decrease employee's well-being and job satisfaction, some conversely, have a good effect on both dimensions. The effect is additionally conditioned by the status of the employee.

Implications for practice: In order to boost the efficiency of the organization through HPWS, the system and the practice of HRM should be individually designed relevant to the company conditions in acceptable to the organization and feasible way, and then it should be implemented in accordance with the adopted assumptions.
\end{abstract}

Keywords: high-performance work systems, organizational performance, human resource management practices

Paper Type: Conceptual paper

\section{Introduction}

Dynamic changes in an organisation's environment and its strong competitiveness as well as the challenges arising from the need to constantly improve the efficiency of teams contribute to the growing interest in the potential benefits of building high-performance work systems (HPWS) as a factor increasing competitive advantage in the market. Research in recent decades has given ample evidence that HPWS is a key factor in the development of the organisation, and increasing its efficiency. Many studies refer not only to the impact of HPWS on efficiency 
SHAPING

HIGH-PERFORMANCE WORK SYSTEMS

Milena Gojny-Zbierowska but also to intervening variables in this relationship. The HPWS model stems from the managerial perspective focused on increasing efficiency through the transformation of employer-employee relations into the partnership arrangement under the common pursue of organisation's objectives. In order to achieve such a relationship it is necessary to use the tools of human resource management that strengthen employee commitment and enhance their participation in decisionmaking, and impact on the organisation's affairs. The use of HRM practice package, which aims to provide a sense of job security, building autonomous teams, as well as providing specialised knowledge and training is a characteristic element of HPWS. The aim of the study is to show the human resource management practices related to HPWS as well as to discuss their implementation in the organisation based on the available literature.

\section{The essence of high-performance work systems}

HPWS is described by many scientists and researchers, but there is no single, universally accepted definition. Analysing the existing definitions one can see similarities, certain common elements. Nadler, Gerstein and Shaw (1992) describe HPWS as organisation's architecture that clusters the work, people, technology and information in a way that optimises their match. This adjustment is aimed at increasing efficiency, understood as an effective way of meeting customer demand and responding to the opportunities and requirements coming from the environment. For Bohlander and Snell (2004), HPWS is a specific combination of HRM practices, structures and processes maximising the knowledge, skills, commitment and flexibility of an employee. This definition suggests that the high-performance work system is a highly efficient system consisting of a series of unrelated components that enable the organisation to achieve its objectives. The central idea of HPWS is to create an environment within the organisation based on participation, dedication and empowerment of the employee, and not on their control (Tomer, 2001). Organisations that implement an employee control-oriented approach assume that the work must be standardised, simple and specialised, and managers should use incentives in the motivation process (Lawler, 1992; Tomer, 2001). On the other hand, organisations implementing HPWS assumptions engage the employee in the processes of procedure improvement, problem-solving, leading to the development of the organisation. In a HPWS environment employees can work without close supervision and without leading them step by step towards the goals, if there is a clearly defined vision, mission and objectives of the organisation. Employees in high-performance work systems are allowed to make full use of their talents, which not only helps in achieving the organisation's objectives, but also enables the fulfilment of employees and evokes the feeling that their work is meaningful (Lawler, 1992). 
3. Human Resources Management practices important for high-performance work systems

Just as there is a lack of consensus about the definition of high-performance work systems, so there is no consensus among researchers regarding its constituent HRM practices. In an influential study of Appelbaum et al. (2000) there were collected thirteen practices which were grouped into four categories. Teamwork is central to HPWS according to Appelbaum et al. (2000). In the authors' opinion, teamwork involves employees at all levels and creates an environment in which employees can make decisions and participate in solving problems affecting their work. This indirectly leads to greater commitment and dedication of employees, and thus, improves the efficiency of the organisation. Motivating also plays a key role in creating and maintaining a successful HPWS. The organisation should motivate by a stimulating environment in which everyone is interested in the development of ideas leading to the improvement of the work efficiency system and, as a result, the efficiency of the organisation. Motivating may take many forms, but in most cases it should be related to the performance of a team. To improve the efficiency, the employee must enhance their competencies through development, mainly conditioned by practice and training leading to the enrichment of their potential, which in turn should lead to increased responsibilities and more demanding and rewarding tasks. The last group of practices is communication. Improving communication allows for better decisions being made faster.

HRM practices discussed by subsequent researchers of the subject overlap, but each of them stresses the importance of other activities. In Table 1 were collected HRM practices, cited as crucial for HPWS by the leading scholars of the issue.

\begin{tabular}{lll}
\hline No. & HRM PRACTICES & AUTHORS \\
\hline 1 & Flexible working conditions & Evans and Davis \\
\hline 2 & Team problem-solving & Appelbaum \\
\hline 3 & Individualization of motivators & Appelbaum \\
\hline 4 & $\begin{array}{l}\text { Informing employees about financial results and the effective- } \\
\text { ness of the company }\end{array}$ & Appelbaum, Pfeffer \\
\hline 5 & Career advancement opportunities & Appelbaum \\
\hline 6 & $\begin{array}{l}\text { Bridging barriers, reduction of differences in the status of } \\
\text { employees at the same level }\end{array}$ & Pfeffer \\
\hline 7 & $\begin{array}{l}\text { Open communication (feedback) allowing for a sincere } \\
\text { expression of opinion }\end{array}$ & $\begin{array}{l}\text { Appelbaum, Ashton and } \\
\text { Sung, Evans and Davis }\end{array}$ \\
\hline \multicolumn{3}{l}{$\begin{array}{l}\text { Extensive training and development programme } \\
\text { Appelbaum, Ashton and }\end{array}$} \\
\hline $\begin{array}{l}\text { Selective recruitment of new employees - the use of a variety } \\
\text { of recruitment and selection methods to identify candidates } \\
\text { with the most sought competencies by the organisation }\end{array}$ & Pfeffer \\
\hline
\end{tabular}

SHAPING HIGH-PERFORMANCE WORK SYSTEMS

Milena Gojny-Zbierowska 
SHAPING

HIGH-PERFORMANCE

WORK SYSTEMS

Milena Gojny-Zbierowska

Table 1. continue

\begin{tabular}{lll}
\hline No. & HRM PRACTICES & AUTHORS \\
\hline 10 & Employment security & Pfeffer \\
\hline 11 & Profit sharing & Appelbaum \\
\hline 12 & $\begin{array}{l}\text { (Attractive) remuneration contingent on the team's and orga- } \\
\text { nisation's performance }\end{array}$ & $\begin{array}{l}\text { Appelbaum, Ashton and } \\
\text { Sung, Evans and Davis, } \\
\text { Pfeffer }\end{array}$ \\
\hline & $\begin{array}{l}\text { Autonomous teams - giving teams the power to manage their } \\
\text { work - decentralised decision-making }\end{array}$ & $\begin{array}{l}\text { Appelbaum, Ashton and } \\
\text { Sung, Evans and Davis, } \\
\text { Pfeffer }\end{array}$ \\
\hline
\end{tabular}

Ashton and Sung (2002) indicate four HRM practices as the key to building HPWS. The authors pay particular attention to the creation of remuneration systems promoting good results and motivating employees (e.g. remuneration based on team or individual performance) as well as to the support of employees in improving their efficiency. This includes measures to ensure a continuous acquisition of new skills such as coaching or mentoring. Ashton and Sung also emphasise the importance of an internal communication system that allows for a clear flow of information, encouraging feedback. It is important that the feedback from employees reached the persons responsible for the organisation's strategy, so that it is part of the employee's participation in the governance process. Evans and Davis (2005) draw attention both to the flexibility as one of the conditions of the system and as a result of introduced HPWS assumptions. The researchers propose seven practices. Although different authors make reference to different HRM practices for building high-performance work systems, the common denominator seems to be one of the first classifications, created by Pfeffer (1998), which distinguishes seven practices. For Pfeffer, the core HPWS idea is employee's commitment and dedication, their empowerment, as well as the rejection of an employee controloriented policy. On the other hand, Gephart and Van Buren (1996) claim that it is the unique needs of the organisation that should determine the choice of practices used to build HPWS because there are no two identical high-performance work systems. Not all possible actions have to be taken to achieve high efficiency. The referred authors see one prerequisite for achieving high efficiency; synergy, which is the result of matching practices to employees.

\section{The positive HPWS dimension - discussion}

Research in the area of human resource management and efficiency also includes studies in the field of high-performance work practices (HPWP). Many scholars claim that the HPWP implementation yields results in the form of increased productivity, increased in efficiency and benefits for employees (Combs et al., 2006). There are many examples of the relationship between HPWS and various 
aspects of the functioning of the organisation, primarily its efficiency (Camps and Luna-Arocas, 2012; Chi and Lin, 2011; Guthrie, 2001; MacDuffie, 1995; Datta et al., 2005; Delaney and Huselid, 1996; Guest et al., 2003; Way, 2002) retention of employees (Arthur, 1994; Guthrie, 2001; Way, 2002) and financial performance (Huselid, 1995; Lee and Miller, 1999) in the literature on strategic human resources management. Research on the relationship between individual practices of highperformance work systems and the effectiveness of the organisation indicates the existence of many dependencies. Welbourne and Andrews (1996) showed that the extent to which organisations appreciate their employees has a positive impact on how a company is managing in the market. Burton and O'Reilly (2004) found a positive relationship between the work systems based on employee participation and the likelihood of keeping a company afloat in the market. Rauch et al. (2005) found a positive correlation between the level of using human resources and employment growth. There has also been found a link between high-performance work systems and innovation. A range of HPWS practices increase the company's level of innovation and entrepreneurship (Hayton, 2005). It is characteristic for innovative companies to provide attractive remuneration, higher than in competing companies. Good earnings motivate to take the risk of investing time in innovative projects (Carlson et al., 2006; Hostager et al., 1998; Soutaris, 2002). In addition, companies showing internally balanced structure of remuneration achieve a higher level of innovation. HPWS is also associated with a higher level of socially responsible behaviour, which also leads to better communication and knowledge sharing (Hayton, 2005). Research conducted by Michie and Sheehan (1999) has shown that companies providing teamwork, self-employment, flexible working conditions and sharing of information launch more new products on to the market than their competitors. A positive correlation between HPWS and the increase in sales has also been proved (Messersmith and Guthrie, 2010; Tregaskis et al., 2013). A number of studies show that companies with culture based on employee involvement as a result of the introduction of the high-performance work system experience lower levels of voluntary redundancies (Arthur, 1994; Guthrie, 2001; Huselid, 1995; Way, 2002), allowing them to retain talented employees, their knowledge base and better utilisation of human capital, which in turn reduces costs and secondarily affects the efficiency of the organisation (Huselid, 1995; Shaw et al., 2005).

Although almost all studies in HPWS emphasise benefits to organisations from the implementation of the system, the consequences for the employee are a more controversial issue. The literature describing the benefits and drawbacks for the employee presents a broad spectrum of opinions, the most important will be cited here. Starting with the arguments in favour of a negative assessment of HPWS, it is worth quoting Danford (2003) who points to the capitalistic nature of the high-performance work system and the objective of profit maximisation.

HIGH-PERFORMANCE WORK SYSTEMS

Milena Gojny-Zbierowska 
SHAPING

HIGH-PERFORMANCE WORK SYSTEMS

Milena Gojny-Zbierowska
There is a relationship between HPWS and the lack of job satisfaction when the employee commitment is used as a mechanism for enlarging the scope of their responsibilities. Studies also show that practices in the high-performance work systems, such as the creation of autonomous teams may have a negative impact on job satisfaction, (Godard, 2004) and also on maintaining a work-life balance (White et al., 2003). The high-performance work system through HRM practices can lead to intensification of work, staying longer in the office at the expense of private life. In addition, the pressure on achievements can lead to tensions and conflicts in employee's private life. Higher levels of employee engagement cause stress, which may be stronger than the positive effects of empowerment or allowing them to make decisions (Godard, 2001). Studies show that after the implementation of HPWS in the organisation the amount of responsibility increases, the level of stress and a feeling of pressure on achieving results rise (Danford, 2003). In the debate on HPWS there has been a polarisation of opinions, some researchers have an enthusiastic attitude to the model, some are highly critical. In an attempt to find the truth between the extremes about the highperformance work systems, Anderson-Connolly, Grunberg, Greenberg and Moore (2002) looked at the various parts of the transformation process of the system and their impact on psychological and physical well-being of employees. The results show the complexity of the issue. Some aspects related to the system transformation decrease employee's well-being and job satisfaction, some conversely, have a good effect on both dimensions. The effect is additionally conditioned by the status of the employee. For example, the autonomy has a positive effect on the regular employee, but it increases the manager's stress level. Similar results were obtained by Batt (2002) Farris and Toyama (2002) or Bauer (2004). Studies showing the positive impact of the HPWS model implementation on employees pay attention to the higher level of job satisfaction, higher earnings and improving professional competence (Ashton and Sung, 2002). Similar results were obtained by Bailey, Berg and Sandy (2001), whose studies have shown that in HPWS employees are better trained and have higher salaries compared with other companies.

Contradictory results about the impact of high-performance work systems on the employee indicate the unique nature of the systems. There are no two identical systems, the configuration of individual elements of HPWS and the external culture influence are factors which despite common assumptions in any organisation create a unique system as well as a different set of benefits and drawbacks related to the transformation of the system.

\section{Conclusion}

In recent decades, many studies have been conducted on high-performance work systems. HPWS most often occurs in studies on the effectiveness of the organisation, which indicate a positive correlation between the existence of HPWS 
and an increase in efficiency. HRM is seen as a factor supporting the building of high-performance work systems, some studies indicate the integral relationship between HPWS and HRM. The HPWS implementation in the organisation is carried out by specific, positive HRM practices. The incorrect implementation of assumed actions within the framework of human resource management may be the threat to achieving increased efficiency despite the establishment of a high-performance work system, which gives an indication of the nature of the application. In order to boost the efficiency of the organisation through HPWS, the system and the practice of HRM should be individually designed relevant to the company in acceptable to the organisation and feasible way, and then it should be implemented in accordance with the adopted assumptions. Despite the great interest in the issue it is difficult to find a common definition or a unified classification of the factors that make up the HPWS and support the implementation of HRM practices. The most frequently cited HRM practises by researchers have been presented in the paper and also the conditions necessary for their implementation have been highlighted here.

Due to the great interest in the topic in Western Europe and the United States, and yet a relatively small popularity of high-performance work systems in the Polish science, the research on identifying how the assumptions of the HPWS model are implemented in the Polish economic conditions would be valuable.

\section{Acknowledgement}

The research was carried out within research project 2014/13/B/HS4/01618 funded by National Science Centre, Poland.

\section{References}

Anderson-Connolly, R., Grunberg, L., Greenberg, E. S., Moore, S. (2002), "Is lean mean? Workplace transformation and employee well-being", Work, Employment and Society, Vol. 16 No. 3, pp. 389-413. DOI: http://dx.doi.org/10.1177/095001702762217407

Appelbaum, E., Bailey, T., Berg, P., Kalleberg, A. (2000), Manufacturing Advantage: Why High-Performance Work Systems Pay Off, ILR Press, Ithaca.

Arthur, J. B. (1994), "Effects of human resource systems on manufacturing performance and turnover", Academy of Management Journal, Vol. 37 No. 3, pp. 670-687.

Ashton, D., Sung, J. (2002), Supporting workplace learning for high performance working, International Labour Office, Geneva.

Bailey, T., Berg, P., Sandy, C. (2001), "The effect of high-performance work practices on employee earnings in the steel, apparel and medical electronics and imaging industries", Industrial and Labor Relations Review, Vol. 54 No. 2A, pp. 525-543.

Batt, R. (2002), "Managing customer services: human resource practices, quit rates, and sales growth", Academy of Management Journal, Vol. 45 No. 3, pp. 587-597. DOI: http://dx.doi.org/10.2307/3069383 
SHAPING HIGH-PERFORMANCE WORK SYSTEMS

Milena Gojny-Zbierowska
Bauer, T. (2004), "High performance workplace practices and job satisfaction: evidence from Europe", Discussion Paper No. 1265, Institute for the Study of Labor (IZA).

Bohlander, G. W., Snell, S. (2004), Managing human resources (13 th ed.), OH: Thomson/ South-Western, Mason.

Burton, M. D., O'Reilly, C. (2004), "Walking the Talk: The Impact of High Commitment Values and Practices on Technology Start-ups", available at: http://works.bepress. com/m_diane_burton/4 (accessed 12 September 2015).

Camps, J., Luna-Arocas, R. (2012), "A Matter of Learning: How Human Resources Affect Organizational Performance”, British Journal of Management, Vol. 23 No. 1, pp. $1-21$.

Carlson, D. S., Upton, N., Seaman, S. (2006), "The impact of human resource practices and compensation design on performance: An analysis of family-owned firms", Journal of Small Business Management, Vol. 44 No. 4, pp. 531-543. DOI: http://dx.doi. org/10.1111/j.1540-627X.2006.00188.x

Chi, N., Lin, C. (2011), "Beyond the High-Performance Paradigm: Exploring the Curvilinear Relationship between High-Performance Work Systems and Organizational Performance in Taiwanese Manufacturing Firms", British Journal of Industrial Relations, Vol. 49 No. 3, pp. 486-514. DOI: http://dx.doi.org/10.1111/j.1467-8543.201 0.00778.X

Combs, J., Liu, Y., Hall, A., Ketchen, D. (2006), "How much do high-performance work practices matter? A meta-analysis of their effect on organizational performance", Personnel Psychology, Vol. 59 No. 3, pp. 501-528. DOI: http://dx.doi.org/10.1111/j .1744-6570.2006.00045.x

Danford, A. (2003), "Workers, unions and the high performance workplace", Work, Employment and Society, Vol. 17 No. 3, pp. 569-587.

Datta, D. K., Guthrie, J. P., Wright, P. M. (2005), "Human resource management and labor productivity: does industry matter?", Academy of Management Journal, Vol. 48 No. 1, pp. 135-145. DOI: http://dx.doi.org/10.5465/AMJ.2005.15993158

Delaney, J. T., Huselid, M. A. (1996), “The Impact of Human Resource Practices on Perceptions of Organizational Performance", Academy of Management Journal, Vol. 39 No. 4, pp. 949-969. DOI: http://dx.doi.org/10.2307/256718

Evans, R., Davis, W. (2005), "High-performance work systems and organizational performance: the mediating role of internal social structure", Journal of Management, Vol. 31 No. 5, pp. 758-775. DOI: http://dx.doi.org/10.1177/0149206305279370

Farris, D., Tohyama, H. (2002), "Productive efficiency and the lean production system in Japan and the United States", Economic and Industrial Democracy, Vol. 23 No. 4, pp. 529-554. DOI: http://dx.doi.org/10.1177/0143831X02234004

Gephart, M. A., Van Buren, M. E. (1996), "Building synergy: The power of high performance work systems", Training and Development, Vol. 50 No. 10, pp. 21-36.

Godard, J. (2001), "High performance and the transformation of work? The implications of alternative work practices for the experience and outcomes of work", Industrial and Labor Relations Review, Vol. 54 No. 4, pp. 776-805. DOI: http://dx.doi. org/10.2307/2696112

Godard, J. (2004), "A critical assessment of the high-performance paradigm", British 
Journal of Industrial Relations, Vol. 42 No. 2, pp. 349-378. DOI: http://dx.doi.org/1 0.1111/j.1467-8543.2004.00318.x

Guest, D., Michie, J., Conway, N., Scheehan, M. (2003), "Human resource management and corporate performance in the UK", British Journal of Management, Vol. 41 No. 2, pp. 291-314. DOI: http://dx.doi.org/10.1111/1467-8543.00273

Guthrie, J. P. (2001), "High-involvement work practices, turnover, and productivity: evidence from New Zealand”, Academy of Management Journal, Vol. 44 No. 1, pp. 180-191. DOI: http://dx.doi.org/10.2307/3069345

Hayton, J. C. (2005), "Promoting corporate entrepreneurship through human resource management practices: A review of empirical research", Human Resource Management Review, Vol. 15 No. 1, pp. 21-41. DOI: http://dx.doi.org/10.1016/j.hrmr. 2005.01.003

Hostager, T. J., Neil, T. C., Decker, R. L., Lorentz, R. D. (1998), “Seeing environmental opportunities: Effects of entrepreneurial ability, efficacy, motivation and desirability", Journal of Organizational Change, Vol. 11 No. 1, pp. 11-25. DOI: http:// dx.doi.org/10.1108/09534819810369536

Huselid, M. A. (1995), "The impact of human resource management practices on turnover, productivity, and corporate financial performance", Academy of Management Journal, Vol. 38 No. 3, pp. 635-672. DOI: http://dx.doi.org/10.2307/256741

Lawler, E. E. (1992), The ultimate advantage: Creating the high involvement organization, Jossey-Bass, San Francisco.

Lee, J., Miller, D. (1999), "People matter: Commitment to employees, strategy and performance in Korean firms", Strategic Management Journal, Vol. 20 No. 6, pp. 579-593. DOI:http://dx.doi.org/10.1002/(SICI)1097-0266(199906)20:6\%3C579:: AID- SMJ37\%3E3.0.CO;2-C

MacDuffie, J. P. (1995), "Human resource bundles and manufacturing performance: organizational logic and flexible production systems in the world auto industry", Industrial and Labor Relations Review, Vol. 48 No. 2, pp. 197-221. DOI: http:// dx.doi.org/10.2307/2524483

Messersmith, J. G., Guthrie, J. P. (2010), "High Performance Work Systems In Emergent Organizations: Implications For Firm Performance", Human Resource Management, Vol. 49 No. 2, pp. 241-264. DOI: http://dx.doi.org/10.1002/hrm.20342

Michie, J., Sheehan, M. (1999), "HRM practices, R\&D expenditure and innovative investment: Evidence from the UK's 1990 Workplace Industrial Relations Survey (WIRS)", Industrial and Corporate Change, Vol. 8 No. 2, pp. 211-234.

Nadler, D. A., Gerstein, M. S., Shaw, R. B. (1992), Organizational architecture: Designs for changing organizations (1 ${ }^{\text {st }}$ ed.), Jossey-Bass, San Francisco.

Pfeffer, J. (1998), The Human Equation: Building Profits by Putting People First, Harvard Business School Press, Boston.

Rauch, A., Frese, M., Utsch, A. (2005), "Effects of human capital and long-term human resources development and utilization on employment growth of small-scale business: A causal analysis", Entrepreneurship: Theory \& Practice, Vol. 29 No. 6, pp. 681-698.

Shaw, J. D., Gupta, N., Delery, J. E. (2005), “Alternative conceptualizations of the rela-
SHAPING HIGH-PERFORMANCE WORK SYSTEMS

Milena Gojny-Zbierowska 
SHAPING

HIGH-PERFORMANCE WORK SYSTEMS

Milena Gojny-Zbierowska tionship between voluntary turnover and organizational performance", Academy of Management Journal, Vol. 48 No. 1, pp. 50-68.

Soutaris, V. (2002), "Firm-specific competencies determinin technological innovation: A survey in Greece", $R \& D$ Management, Vol. 32 No. 1, pp. 61-77.

Tomer, J. (2001), "Understanding High-Performance Work Systems: the Joint Contribution of Economics and Human Resource Management", The Journal of Socio-Economics, Vol. 30 No. 1, pp. 63-73. DOI: http://dx.doi.org/10.1016/S1053-5357(01)00093-2

Tregaskis, O., Daniels, K., Glover, L., Butler, P., Meyer, M. (2013), "High Performance Work Practices and Firm Performance: A Longitudinal Case Study", British Journal of Management, Vol. 24 No. 2, pp. 225-244. DOI: http://dx.doi.org/10.1111/j.1467 $-8551.2011 .00800 . \mathrm{x}$

Way, S. (2002), "High performance work systems and intermediate indicators of firm performance within the US small business sector", Journal of Management, Vol. 28 No. 6, pp. 765-785. DOI: http://dx.doi.org/10.1177/01490630202800604

Welbourne, T. M., Andrews, A. O. (1996), "Predicting the performance of initial public offerings: Should human resource management be in the equation?", Academy of Management Journal, Vol. 39 No. 4, pp. 891-919. DOI: http://dx.doi.org/10.2307/256716

White, M., Hill, S., McGovern, P., Mills, C., Smeaton, D. (2003), "High-Performance Management Practices, Working Hours and Work-Life Balance", British Journal of Industrial Relations, Vol. 41 No. 2, pp. 175-195. DOI: http://dx.doi. org/10.1111/1467-8543.00268 